\title{
ESTIMATION OF DEMAND FOR DIRECT AND INDIRECT USES OF MANGROVE RESOURCES IN MUTHURAJAWELA AND NEGOMBO AREA
}

\author{
ASC Wilson and DMSHK Ranasinghe \\ Department of Forestry and Environmental Science \\ University of Sri Jayewardenepura, Nugegoda
}

In Sri Lanka the coastal vegetation and seashore vegetation cover a good part of the coastline. Mangrove community is one of prominent vegetation along the coastline of Sri Lanka. Mangroves represent $1 \%$ of the total forest cover of Sri Lanka. About 29 mangrove species have been identified in the country. $60 \%$ of the mangroves are found in Western to North Western coastal belt; Colombo to Puttalam, North Eastern to Southern coastal belt; Trincomallee to Kalametiya and Jaffna peninsula. This study was conducted to estimate the demand for mangrove resourses and has attempted to correlate it with the population increase in Muthurajawela and Negombo area.

3 villages were selected from each of the 3 DS divisions in Muthurajawela and Negombo area; Wattala, Ja-Ela and Negombo. From each village, five houses were selected randomly that are highly dependent on mangrove resources. The data was collected by questionnaire survey, transect walks through the area, conversations with the community, past and present population records from Divisional Secretaries and Gramaniladhri records.

The culture of the people living in the Muthurajawela and Negombo area links with Muthurajawela marsh and Negombo lagoon. 12 major uses of mangrove resources such as fire wood and timber, food, for fishery, mats and baskets from mangroves, tannin, lime, agriculture, aquaculture, animal feeds, corks and floats, medicine and fish food and baits were recorded. Under these major uses number of minor use of mangrove resource are recorded.

There are 43 Gramaniladhari Divisions in the Muthurajawela and Negombo area. The total population of that in 1990 were 208,615 . In year 2001 the population is 231,588 . The population growth is 2.45 per year. But the population growth in the island is $1.6 \%$ per year. So there is a significant increase of population growth in the study area.

In this study area $90 \%$ of the houses are temporary structures $97 \%$ with cadjan roofs and plank walls. Mangroves provided the timber for the roofs. Fuel wood for cooking is sometimes purchased and most are collected from the marsh. Household waste is scattered in the marsh. As the result of the population increase in last 10 years the demand for most of the mangrove resources has increased. There is a significant increase of garbage dumping in Muthurajawela marsh during this decade. 